\title{
GAMBARAN KESEJAHTERAAN SPIRITUAL PADA PASIEN CHRONIC KIDNEY DISEASE (CKD) DI RSUD Dr. M. YUNUS BENGKULU
}

\author{
Nova Yustisia, Titin Aprilatutini, Tiara Dwi Rizki \\ Prodi Keperawatan FMIPA Universitas Bengkulu \\ Email: nyustisia@unib.ac.id
}

\begin{abstract}
ABSTRAK
Kesejahteraan spiritual merupakan salah satu faktor penunjang kesembuhan pasien. Kesejahteraan spiritual pada pasien CKD sangat penting untuk diperhatikan. Pada penelitian ini, peneliti menggunakan jenis rancangan penelitian Studi Deskriptif Kuantitatif dengan pendekatan studi kasus. Sampel yang diambil adalah 10 orang pasien CKD maksimal 8 kali yang melakukan hemodialisa. Instrument pengumpulan data yang digunakan pada penelitian ini adalah kuesioner dari Ellison yaitu kuesioner Spiritual Well Being Scale (SWBS). Hasil dari penelitian ini menunjukkan lebih dari sebagian $(60 \%)$ responden memiliki kesejahteraan spiritual dalam katagori baik. Responden dengan nilai kesejahteraan spiritual baik menganggap bahwa penyakitnya adalah ujian dari Tuhan dan merasa bahwa dibalik penyakitnya pasti ada hikmahnya dan hampir sebagian (40\%) responden memiliki kesejahteraan spiritual dalam katagori kurang baik menunjukkan bahwa responden tidak menerima penyakitnya, responden mengatakan bahwa Tuhan itu tidak adil terhadapnya. Peneliti melihat dari wajah responden terlihat sedih, dan merasa putus asa akibat penyakit yang dideritanya. Jadi perlu peran perawat untuk memberi perhatian lebih khususnya pada kesejahteraan spiritual, agar terciptanya tingkat kesejahteraan spiritual pasien CKD yang lebih optimal.
\end{abstract}

Kata Kunci : Kesejahteraan Spiritual, Chronic Kidney Disease (CKD)

\section{Description Of Spiritual Welfare In Chronic Kidney Disease (Ckd) Patients In RSUD Dr. M. Yunus Bengkulu}

\begin{abstract}
Spiritual well-being is one of the factors supporting the patient's recovery. therefore, spiritual welfare in CKD patients is very important to note. In this study, researchers used a type of research design Descriptive Quantitative Studies with cases studies. The purpose of this study was to describe the spiritual welfare of CKD patients in Dr. M. Yunus Bengkulu. Samples taken were 10 patients CKD maximum 8 times that do hemodialisa. Instrument of data collection used in this research is questionnaire. The results of this study show that almost all $(60 \%)$ of respondents have spiritual well-being in good category, the respondent with spiritual welfare value both indicates that the illness is a test from God and feel that behind the illness there must be wisdom and almost some (40\%) respondents have prosperity spiritual in the less good category indicates that the respondent did not accept the illness, the respondent said that God is unfair, the researcher see from the respondent's face look sad, and feel despair due to illness he suffered. So it is necessary for the nurse's role to pay more attention especially to spiritual welfare, in order to create a more optimal level of spiritual welfare of CKD patients.
\end{abstract}

Keywords : Spiritual well-being, Chronic Kidney Disease (CKD) 


\section{Latar Belakang}

Penyakit kronik merupakan suatu penyakit yang perjalanan penyakitnya berlangsung lama sampai bertahun-tahun, bertambah berat, menetap, dan sering kambuh. Penyakit kronis bisa menyebabkan kematian. Contoh penyakit kronis adalah diabetes melitus, TBC, kanker, penyakit jantung, dan Chronic Kidney Disease (CKD) (Potter and Perry, 2010).

CKD didefinisikan sebagai kelainan fungsi ginjal atau struktur ginjal selama lebih dari 3 bulan, terjadi penurunan kecepatan filtrasi glomerulus (Glomerular Filtration Rate - GFR) kurang dari 60 $\mathrm{mL} / \mathrm{min} / 1,73 \mathrm{~m} 2$ dengan atau tanpa kerusakan ginjal (KDOQI, 2002 dalam The Australian Kidney Foundation 3rd Edition, 2015). Dimana kemampuan tubuh gagal untuk mempertahankan metabolisme dan keseimbangan cairan dan elektrolit, menyebabkan uremia (retensi urea sampah nitrogen lain dalam darah) (Muttaqin, 2011).

Penyakit ginjal kronik menjadi masalah besar dunia karena sulit disembuhkan, biaya perawatan dan pengobatannya yang terhitung mahal. Penyakit ini akan menyerang siapa pun, tidak memandang usia, suku dan jenis kelamin maupun tingkat sosial ekonomi. CKD merupakan masalah kesehatan dunia dengan peningkatan insiden, serta tingkat angka kejadian 65-200 penderita per 1 juta penduduk. Tahun 2015 diperkirakan ada 36 juta penduduk meninggal akibat penyakit ginjal kronik.

\section{Chronic Kidney Disease} (CKD) disebabkan terjadinya peningkatan ureum dalam darah. Ureum adalah sisa hasil ikatan metabolisme protein dan asam amino yang di ekskresi melalui ginjal, karena ginjal mengalami gangguan fungsi yang mengakibatkan retensi kadar ureum dalam darah. Pasien Chronic Kidney Disease (CKD) sistem tubuhnya selalu dipengaruhi oleh kondisi uremia, oleh karena itu pasien akan memperlihatkan sejumlah tanda dan gejala seperti hipertensi, pitting edema, edema periorbital, pembesaran vena leher, sehingga pasien Chronic kidney Disease (CKD) dianjurkan melakukan hemodialisa (Haryono, 2013).

Hemodialisa adalah suatu teknologi tinggi sebagai terapi pengganti fungsi ginjal untuk mengeluarkan sisa-sisa metabolisme atau racun tertentu dari peredaran darah manusia seperti air, natrium, kalium, hydrogen, urea, kreatinin, asam urat, dan zat-zat lain melalui membran semi permeable sebagai pemisah darah dan cairan dialisat pada ginjal buatan di mana terjadi proses difusi, osmosis dan ultrafiltrasi (Haryono, 2013).

Kenyataan bahwa pasien CKD tidak bisa lepas dari hemodialisa sepanjang hidupnya menimbulkan dampak psikologis yang menyebabkan terjadinya kehilangan sesuatu yang sebelumnya ada seperti kebebasan, pekerjaan dan kemandirian. Hal ini bisa menimbulkan gejala-gejala depresi yang nyata pada pasien gagal ginjal sampai dengan tindakan bunuh diri. Selain itu masalah ketergantungan hemodialisa juga berdampak pada masalah ekonomi karena hemodialisa pada umumnya 4-5 jam dan dilakukan 2-3 kali dalam seminggu sehingga membutuhkan biaya yang tidak sedikit dan menyebabkan beban pikiran pada keluarga. 
$\begin{array}{ccc}\text { Respon } & \text { setiap } & \text { pasien dalam } \\ \text { melakukan } & \text { terapi } & \text { hemodialisa }\end{array}$ berbeda-beda seperti akan merasa cemas akibat krisis situasional, ancaman, kematian dan tidak mengetahui hasil akhir dari terapi yang dilakukan tersebut.

Pasien CKD sangat memerlukan kebutuhan spiritual karena spiritual dapat memengaruhi kehidupan seseorang. Memenuhi kebutuhan spiritual pasien dapat meningkatkan perilaku koping dan kekuatan dalam menghadapi suatu penyakit. Efek dari tidak terpenuhinya kebutuhan spiritual pada pasien CKD yang tidak mempunyai kepercayaan dan keyakinan bisa mengalami keputusasaan karena tidak mengetahui tujuan hidupnya, distress spiritual dan dapat juga seseorang akan jauh lebih rentan terhadap depresi, stres, mudah gelisah, kehilangan motivasi yang mungkin membuat seseorang merasa sendiri dan terisolasi dari orang lain (Potter and Perry, 2010).

Kesejahteraan spiritual adalah proses menguraikan sifat ikatan yang dinamis antara pribadi dan pencipta, hubungannya cukup harmonis tergantung pada pengembangan diri yang dilakukan secara sengaja, biasanya datang atas dasar kesesuaian antara pengalaman hidupnya yang bermakna, memiliki tujuan dan nilai-nilai kehidupan pribadi (Ellison, 1983). Kebutuhan spiritual merupakan kebutuhan dasar setiap individu untuk mencari tujuan hidup, memaknai hidup untuk mencintai dan dicintai.

Individu

mungkin

mempertanyakan nilai spiritual mereka, tujuan hidup, jalan hidup seluruhnya dari makna hidupnya (Craven \& Hirnle, 2000), sedangkan jika kebutuhan spiritual terpenuhi maka akan mengurangi kecemasan dan penurunan distress, individu akan lebih mampu memaknai masalah yang dihadapinya.

Hasil survey awal di RSUD M.Yunus Bengkulu didapat data pasien dalam rekam medik terdapat 930 kasus yang menderita CKD pada tahun 2015, dan terdapat 1102 kasus pada tahun 2016, dan terdapat 1739 kasus pada tahun 2017 (Medical Record RSUD Dr. M.Yunus Bengkulu, 2018).

Hasil studi pendahuluan yang penulis lakukan di ruang Hemodialisa RSUD Dr. M.Yunus didapatkan di ruang $H D$ ada 21 pasien yang sedang melakukan cuci darah. Hasil wawancara terhadap 2 pasien hemodialisa tentang pemenuhan kebutuhan spiritual di dapatkan jawaban bahwa pasien 1 yang mengatakan, hanya bisa mengandalkan cuci darah saja, dan pasrah terhadap hidupnya. Sedangkan pasien ke 2 merasa baikbaik saja, mampu mengendalikan diri dengan beribadah, sholat sebagai sarana untuk mendekatkan diri dengan Tuhan serta pasrah dengan kondisinya saat ini namun selalu ada usaha untuk sembuh.

Berdasarkan hal tersebut di atas penulis tertarik melakukan penelitian tentang "Gambaran Kesejahteraan Spiritual pada pasien Chronic Kidney Disease (CKD) di RSUD Dr. M.Yunus Bengkulu 2018".

\section{Tujuan Penelitian}

Tujuan umum pada penelitian ini untuk menggambarkan kesejahteraan spiritual pasien Chronic Kidney Disease (CKD) di RSUD Dr. M. Yunus Bengkulu, dan tujuan Khusus nya (1). Untuk dapat menggambarkan kesejahteraan spiritual melalui hubungan dengan 
Tuhan pasien Chronic Kidney Disease (CKD); (2). Untuk dapat menggambarkan kesejahteraan spiritual melalui hubungan dengan kepuasan diri sendiri pasien Chronic Kidney Disease (CKD)

\section{Metode Penelitian}

Pada penelitian ini peneliti menggunakan metode deskriptif dengan rancangan penelitian studi kasus dimana rancangan penelitian yang mencangkup pengkajian satu unit penelitian secara intensif misalnya satu klien, keluarga, kelompok, komunitas, atau institusi. Meskipun jumlah subjek cenderung sedikit namun jumlah variabel yang diteliti sangat luas. Rancangan dari studi kasus bergantung pada keadaan kasus namun tetap mempertimbangkan faktor penelitian, sehingga akan didapatkan gambaran mengenai satu unit subjek secara jelas (Nursalam, 2013). Populasi dalam penelitian adalah subjek yang memenuhi kriteria yang telah ditetapkan. Populasi dalam penelitian ini Pasien Chronic Kidney Disease (CKD) yang di rawat di RSUD M. Yunus Bengkulu yang berjumlah 30 orang. Sampel penelitian ini adalah Pasien Chronic Kidney Disease (CKD) yang terdapat di Ruang Hemodialisa RSUD M. Yunus Bengkulu sebanyak 10 sampel yang maksimal 8 kali melakukan hemodialisa selama 1 bulan terakhir di ruangan Hemodialisa. Sampel yang diambil harus memiliki kriteria inklusi dan ekslusi. Dimana kriteria inklusi pada penelitian ini yaitu seperti klasifikasi CKD, usia, jenis kelamin, dan pasien yang baru menjalankan/melakukan hemodialisa. Fokus Studi Kesejahteraan spiritual pada pasien Chronic Kidney Disease (CKD).
Definisi

Operasional;

Kesejahteraan spiritual yang dimaksud adalah pernyataan pasien CKD tentang apa yang dirasakan tentang kesejahteraan spiritualnya.

Instrument yang digunakan dalam pengukuran Spiritual Well Being Scale (SWBS) milik Ellison dimana skala ini bersifat netral, tidak mengacu pada agama tertentu sehingga skala ini aman juga jika digunakan untuk semua agama. Kuesioner SWBS terdapat 20 item dalam alat ukur ini, terdiri dari 10 aitem yang mengukur yang mengukur religious well-being dan 10 aitem yang mengukur existential well-being. Setiap item terdiri dari 6 pilihan skala dan responden diharuskan memilih skala yang paling sesuai dengan dirinya.

\section{Hasil Penelitian}

\section{Kesejahteraan Spiritual}

Tabel. 1 Distribusi Frekuensi Kesejahteraan Spiritual (SWBS) di Ruang Hemodialisa RSUD dr. M. Yunus Bengkulu $(\mathrm{n}=10)$.

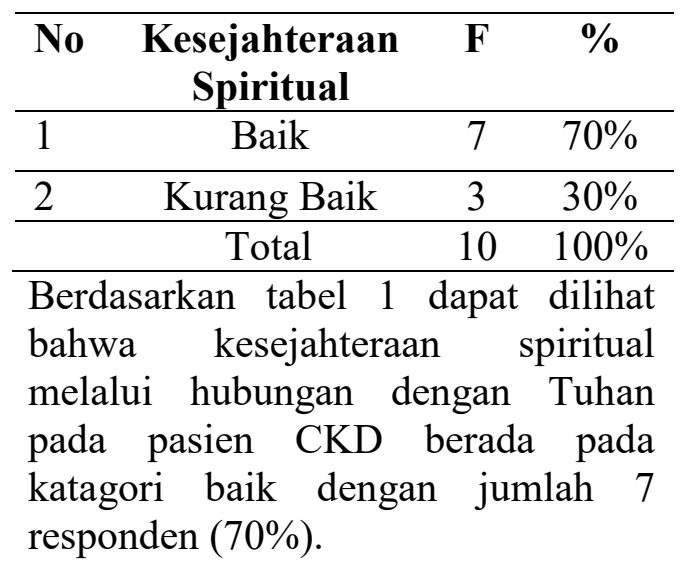

\section{Kesejahteraan Spiritual Melalui Hubungan Dengan Tuhan}

Tabel 2. Distribusi Frekuensi Relationship With Higher Power di Ruang Hemodialisa RSUD dr. M. Yunus Bengkulu $(\mathrm{n}=10)$. 


\begin{tabular}{cccc}
\hline No & $\begin{array}{c}\text { Relationship with } \\
\text { higher power } \\
\text { (Hubungan } \\
\text { Dengan Tuhan) }\end{array}$ & F & \% \\
\hline 1 & Baik & 6 & $60 \%$ \\
\hline 2 & Kurang Baik & 4 & $40 \%$ \\
\hline & Total & 10 & $100 \%$ \\
\hline & & &
\end{tabular}

Berdasarkan tabel 2 dapat dilihat bahwa kesejahteraan spiritual melalui hubungan dengan Tuhan pada pasien CKD berada pada katagori baik dengan jumlah 6 responden $(60 \%)$.

\section{Kesejahteraan Spiritual Melalui Kepuasan Diri Sendiri}

Tabel 3 Distribusi Frekuensi Satisfaction With Self In The World di Ruang Hemodialisa RSUD dr. M. Yunus Bengkulu $(\mathrm{n}=10)$.

\begin{tabular}{lccc}
\hline No & $\begin{array}{c}\text { Relationship } \\
\text { with higher } \\
\text { power } \\
\text { (Kepuasan Diri } \\
\text { Sendiri) }\end{array}$ & F & \\
\hline 1 & Baik & 8 & $80 \%$ \\
\hline 2 & Kurang Baik & 2 & $20 \%$ \\
\hline & Total & 10 & $100 \%$ \\
\hline
\end{tabular}

Berdasarkan tabel 3 dapat dilihat bahwa kesejahteraan spiritual melalui hubungan dengan diri sendiri pada pasien CKD berada pada katagori baik dengan jumlah 8 responden $(80 \%)$.

\section{Pembahasan}

Hasil analisis deskriptif dari kesejahteraan spiritual pasien CKD yang menjalani terapi hemodialisa di RSUD dr. M. Yunus Bengkulu menunjukkan bahwa hampir seluruh (70\%) responden memiliki tingkat kesejahteraan spiritual dalam kategori baik. Hasil penelitian ini sejalan dengan hasil penelitian Indah,
(2015) yang menunjukkan bahwa pasien CKD yang menjalani terapi hemodialisa mayoritas responden memiliki tingkat kecerdasan spiritual dalam kategori baik. Kecerdasan spiritual akan menciptakan kesejahteraan spiritual.

Hal ini dibuktikan oleh item pernyataan no 10 bahwa "saya merasakan kesejahteraan tentang arah hidupnya" dengan rata-rata $(60 \%)$ yang setuju. Selanjutnya item pernyataan no 4 bahwa "saya merasa bahwa hidup adalah pengalaman positif" dengan rata-rata $(70 \%)$ yang setuju. Hal ini dapat terjadi karena responden merasakan jika dekat dengan Tuhan dapat membuat hidup lebih terarah dan penuh harapan tentang masa depan. Selain itu menjalin hubungan positif dan dinamis melalui keyakinan, rasa saling percaya dan cinta kasih serta merasakan kehidupan yang terarah yang terlihat melalui harapan, maka seseorang tidak akan mengalami kesulitan. Hal ini sejalan dengan konsep Perry \& Potter, (2010) bahwa Perasaan mengetahui makna hidup yang kadang diidentikkan dengan perasaan dekat dengan Tuhan, merasa hidup sebagai suatu pengalaman yang positif seperti membicarakan tentang situasi yang nyata, membuat hidup lebih terarah, penuh harapan tentang masa depan, merasa mencintai dicintai oleh orang lain, merasakan kegembiraan, dan menerima penderitaan serta kematian.

Hasil analisis berdasarkan kesejahteraan spiritual yang kurang baik didapati hanya sebagian $(30 \%)$ responden. Hal ini dibuktikan oleh item pernyataan no 16 bahwa "saya merasa hidup penuh dengan masalah dan ketidak bahagiaan" dengan ratarata $(80 \%)$ yang setuju. Hal ini karena responden tidak bisa 
menerima pendapat orang lain hanya menganggap pendapatnya yang benar secara mutlak, tidak mau berdoa dan beribadah karena pada saat dia beribadah doanya belum juga dikabulkan oleh Tuhan, dan tidak ingin percaya bahwa Tuhan peduli padanya, dan menganggap bahwa hidup ini penuh dengan masalah/ konflik yang tidak ada habisnya. Hal ini juga menunjukkan bahwa responden belum dapat menerima penyakitnya, responden mengatakan bahwa Tuhan itu tidak adil, peneliti melihat wajah responden terlihat sedih, dan merasa putus asa kemungkinan disebabkan karena beberapa faktor lain yaitu keterbatasan ekonomi, status pekerjaan memberikan dampak langsung pada pasien, apabila penghasilan yang didapatkan kurang atau tidak ada, maka akan memengaruhi dukungan untuk menunjang kesembuhan pasien, dengan kata lain jika pendapatannya menurun maka semangat untuk sembuh pasien relatif menurun, kurang dukungan keluarga dan jauh dari Tuhan. Anggota keluarga yang memiliki agama dan dekat dengan tuhannya akan memberikan dukungan spiritual kepada angggota yang lainnya. Hasil penelitian ini sejalan dengan Afriadi, (2016) bahwa responden penelitian ini belum sepenuhnya mampu merasakan kehadiran Tuhan dalam kehidupannya.

Hal ini sejalan dengan konsep Ellison, (1983) bahwa kebermaknaan, ketidakpuasan dengan hidup dan merasa ada jarak dengan Tuhan. Hal ini bukan berarti seseorang yang merasa tidak puas dengan hidup dan merasa ada jarak antara dirinya dengan Tuhan akan mendapatkan kesejahteraan spiritual, melainkan sebaliknya. Seseorang yang merasa mempunyai jarak dengan Tuhan, merasa tidak puas dengan kehidupan yang dijalaninya saat ini, maka tidak akan mendapatkan kesejahteraan spiritual, karena hatinya tertutup.

Setiap orang akan mengalami proses perkembangan spiritual sesuai dengan pertambahan usia. Pada penelitian ini mayoritas responden berada pada katagori lansia. Perasaan kehilangan karena pensiun dan tidak bisa bekerja lagi menimbulkan rasa kesepian dan rendah diri. Perkembangan filosofi agama yang lebih matang sering dapat membantu orang lain untuk menghadapi kenyataan, berperan aktif dalam kehidupan dan merasa berharga serta lebih dapat menerima kematian sebagai sesuatu yang tidak dapat ditolak atau dihindarkan (Hamid, 2009). Jadi peran perawat unutk meningkatkan kebutuhan spiritual pada pasien sangat penting agar pasien termotivasi untuk sembuh.

Berdasarkan hasil penelitian yang disajikan dalam tabel 2. dapat diketahui bahwa kesejahteraan spiritual melalui hubungan dengan Tuhan pada pasien CKD berada pada katagori baik yaitu 6 responden $(60 \%)$. Hal ini dibuktikan oleh item pernyataan no 15 bahwa " hubungan saya dengan Tuhan membantu saya untuk tidak merasa kesepian" dengan rata-rata $(60 \%)$ yang setuju. Selanjutnya item pernyataan no 11 bahwa "saya percaya bahwa Tuhan memperhatikan masalah saya" dengan rata-rata $(70 \%)$ yang setuju.

Hal ini sejalan dengan pernyataan Tuti (2015) bahwa pasien merasakan adanya hubungan yang bermakna dengan Tuhan melalui doa dan munculnya harapan, kekuatan terhadap kesembuhan penyakitnya. Manusia juga dapat merasa memiliki makna dari berbagai hal, agama 
(religi) mengarahkan manusia untuk mencari makna dengan pandangan lebih jauh dan bermakna di hadapan Tuhan tidaklah kekal. Peningkatan kesejahteraan spiritual juga terjadi karena pasien merasa hidupnya sejahtera dan Tuhan memperhatikan apa yang terjadi padanya serta adanya kepercayaan yang bermakna dalam hidupnya. Hal tersebut sesuai dengan konsep yang dijelaskan oleh Yusuf, (2016) menyatakan bahwa Penyakit kronis dapat berpengaruh terhadap hubungan dengan Tuhan menyangkut iman dan harapan hidup. Seseorang dengan penyakit kronis sering menganggap dirinya berbeda dengan orang lain dan mulai merasakan kesepian yang mendalam. Hubungan dengan Tuhan dapat mempengaruhi kesepian pasien pada penyakitnya.

Hasil analisis berdasarkan kesejahteraan spiritual melalui hubungan dengan Tuhan yang kurang baik didapati hanya sebagian (40\%). Hal ini dibuktikan oleh item pernyataan no 3 bahwa "saya percaya bahwa Tuhan peduli terhadap saya" dengan rata-rata $(60 \%)$ yang tidak setuju. Selanjutnya item pernyataan no 9 bahwa "saya tidak mendapat banyak kekuatan dan dukungan dari Tuhan saya" dengan rata-rata $(60 \%)$ yang setuju. Hal ini dapat terjadi karena responden tidak merasakan dukungan yang interpersonal baik dengan orang lain maupun Tuhan.

Berdasarkan hasil penelitian yang disajikan dalam tabel 3. dapat diketahui bahwa kesejahteraan spiritual melalui hubungan dengan kepuasan diri sendiri pada pasien CKD berada pada katagori baik yaitu 8 responden $(80 \%)$. Hal ini dibuktikan oleh item pernyataan no 6 bahwa "saya merasa tidak nyaman/takut dengan masa depan saya" dengan rata-rata $(60 \%)$ yang tidak setuju. selanjutnya item pernyataan no 12 bahwa "saya tidak menikmati banyak hal tentang hidup saya" dengan rata-rata $(90 \%)$ yang setuju. hal ini dapat terjadi karena responden hampir seluruh merasa sudah nyaman dan sudah menikmati hidup selama di dunia. Hal ini sejalan dengan hasil peneliti Indah, (2015) bahwa kesejahteraan spiritual melalui hubungan dengan kepuasan diri sendiri pada pasien CKD sudah optimal dikarenakan kesadaran perawat dalam mendukung hubungan yang baik dan peduli terhadapnya dapat menyembuhkan bagi pasien, sehingga pasien dapat menemukan harapan hidup yang lebih positif meskipun dalam kondisi klinis yang tidak mendukung.

Hasil analisis berdasarkan kesejahteraan spiritual melalui hubungan dengan kepuasan diri sendiri yang kurang baik didapati hanya sebagian (20\%). Hal ini dibuktikan oleh item pernyataan no 8 bahwa "saya merasa sangat puas dengan kehidupan saya" dengan ratarata $(50 \%)$ yang tidak setuju. hal ini terjadi karena ada sebagian responden merasa kurang puas, dan kurang memaknai arti kehidupan dalam menjalani hidunya. Hasil penelitian ini sejalan dengan Afriadi (2016) bahwa responden belum mengembangkan beberapa bagian dari dirinya sendiri sama sekali dan masih ingin menjadi pribadi yang bermanfaat bagi diri sendiri, orang lain dan lingkungan sekitar. Hal ini sesuai dengan konsep Hamid (2009) bahwa kesejahteraan spiritual existensial merupan proses bagaimana individu menyikapi diri dalam hidupnya, dan dapat memaknai tujuan hidup, merasa damai dalam hidupnya, percaya 
terhadap orang lain dan lingkungan sekitar.

\section{Simpulan}

Berdasarkan hasil penelitian yang peneliti lakukan, disimpulkan :

1. Pasien CKD di ruang Hemodialisa RSUD dr. M. Yunus Bengkulu yang mayoritas kesejahteraan spiritualnya baik $(60 \%)$ responden dan minoritas kesejahteraannya kurang baik (40\%) responden.

2. Mayoritas kesejahteraan spiritual melalui hubungan dengan Tuhan pada pasien CKD berada pada katagori baik dengan jumlah 6 responden $(60 \%)$.

3. Mayoritas kesejahteraan spiritual melalui hubungan dengan diri sendiri pada pasien CKD berada pada katagori baik dengan jumlah 8 responden $(80 \%)$.

\section{Saran}

1. Bagi Akademik

Penelitian ini dapat menjadi tambahan literatur bagi institusi Keperawatan mengenai aspek spiritual guna menciptakann karakteristik perawat dengan spiritualitas tinggi guna memenuhi kesejahteraan spiritual pasien terhadap penyakit pada pasien CKD.

2. Bagi Tempat Penelitian

Hasil penelitian ini dapat menjadi tambahan data dasar dalam perbaikan mutu asuhan keperawatan di Rumah sakit khususnya asuhan keperaweatan pada penyaklit kronis dengan memperhatikan aspek spiritual pasien yang akan berpengaruh terhadap klualitas hidup pasien

3. Bagi Peneliti lanjut

Hasil penelitian ini merupakan data dasar untuk penelitian selanjutnya. Peneliti berharap adanya penelitian lanjut terkait faktor-faktor lain yang mempengaruhi tingkat kecemasan pada pasien CKD.

\section{Daftar Pustaka}

Andrew S. Levey, MD. 2002. National Kidney Foundation. Tersedia pada: https://www.kidney.org/sites/def ault/files/docs/ckd evaluation cl assification stratification.pdf

Anggriani, Tuti. U. 2015. Perbedaan Kesejahteraan Spiritual Pasien Sebelum Dan Sesudah Operasi Jantung Di RSUP Dr. Hasan Sadikin Bandung [Tesis]. Bandung: Institut Universitas Padjajaran

Craven, Hirnle. 2000. Fundamentals of Nursing. Philadelphia: Lippincott.

Dermawan, Afrida. 2017. Hubungan Kesejahteraan Spiritual Dengan Tingkat Kecemasan Pasien Gagal Ginjal Kronik Di Rsud Kraton Kabupaten Pekalongan [Skripsi]. Pekalongan: Program Studi Sarjana Keperawatan STIKES Muhamadiah

Haryono, Rudi. 2013. Keperawatan Medikal Bedah: Sistem Perkemihan. Edisi 1. Yogyakarta: Rapha Publishing.

Hidayat, A. 2009. Metode Penelitian Keperawatan dan Teknik Analisis Data. Jakarta: Salemba Medika.

Kozier. Erb, Berman. Snyder. 2010. Buku Ajar Fondamental Keperawatan: Konsep, Proses \& Praktik, Volume : 1, Edisi : 7, EGC : Jakarta

Lestari, Indah. 2015. Kesejahteraan Spiritual Pada Pasien Gagal Ginjal Kronik Di Rumah Sakit Umum Aceh [Tesis]. Aceh: Institut Universitas Syiah Kuala Banda Aceh 
Medical Record. 2018. Data Pasien Penyakit Ginjal Kronik. Bengkulu

Mirwanti, Ristina. 2016. Hubungan Kesejahteraan Spiritual Dengan Depresi Pada Pasien Dengan Penyakit Jantung Koroner (PJK). Jurnal Ilmiah Ilmu-Ilmu Kesehatan. 14 (1): 45

Nursalam. 2013. Konsep Dan Penerapan Metodologi Penelitian Ilmu Keperawatan: Pedoman Skripsi, Tesis, dan Instrumen Penelitian Keperawatan. Jakarta: Salemba Medika.

Perry \& Potter. 2010. Fundamental Keperawatan. Jakarta: EGC.

Yusuf, Ah. Dkk. 2016. Kebutuhan Spiritual: Konsep dan Aplikasi Dalam Asuhan Keperawatan. Jakarta: Mitra Wacana Media. 